\title{
Analisis Kategori Literasi Sains pada Buku Siswa IPA Terpadu SMP/MTs Kelas VIII Semester 1 Kurikulum 2013
}

\section{Analysis of Scientific Literacy on Integrated Science $8^{\text {th }}$ Grade $1^{\text {st }}$ Semester at Students' Book of SMP/MTs with 2013 Curriculum}

\author{
Idah Hamidah ${ }^{\rtimes}$, Anilia Ratnasari, dan Surinah \\ Program Studi Pendidikan Biologi, Fakultas Keguruan dan IImu Pendidikan, Universitas Wiralodra, \\ Indramayu, 45213, Indonesia \\ Email: idah.hamidah@unwir.ac.id
}

\begin{abstract}
Abstrak. Penelitian ini bertujuan mendeskripsikan tingkat literasi sains pada buku siswa SMP/MTs kelas VIII semester 1 pada kurikulum 2013 yang meliputi sains sebagai batang tubuh, sains sebagai cara berfikir, sains sebagai cara menyelidiki dan interaksi sains, teknologi dan masyarakat. Jenis penelitian yang digunakan pada penelitian ini adalah metode penelitian kualitatif untuk memahami literasi sains dengan metode analisisisi. Penelitian ini menggunakan teknik purposive sampling pada buku IPA yang digunakan di Kabupaten Indramayu, penentuan bab yang akan dianalisis pada buku menggunakan teknik random. Berdasarkan hasil penelitian diperoleh simpulan bahwa tingkat literasi ilmiah buku siswa IPA SMP/MTs kelas VIII yang digunakan di Kabupaten Indramayu cukup baik sesuai dengan kriteria penilaian. Dimensi literasi sains yang banyak muncul pada buku teks pelajaran IPA yang dianalisis adalah sains sebagai batang tubuh pengetahuan, diikuti sains sebagai jalan investigasi, sains sebagai jalan berpikir dan sains dan interaksinya dengan teknologi dan masyarakat.
\end{abstract}

Kata Kunci: Analisis buku; IPA Terpadu; Literasi Sains; SMP/MTs

\section{Pendahuluan}

Belajar merupakan suatu upaya yang dilakukan seseorang untuk memperoleh perubahan dalam bentuk peningkatan kualitas tingkah laku, kecakapan, pemahaman, keterampilan, daya pikir dan pengetahuan melalui pengalaman (Luzyawati dan Hidayah, 2019). Pengalaman belajar dapat diperoleh melalui sumber belajar.
Sumber belajar salah satunya adalah bahan ajar (Hamidah, 2017). Dimana bahan ajar bias berbentuk cetak yaitu buku. Berbagai banyak buku yang dijadikan sumber belajar bagi siswa. Namun, tidak semua buku yang dijadikan sumber belajar mengandung literasi sains. Literasi sains menurut Programme for International Student 
Assesment (PISA) diartikan sebagai kemampuan menggunakan pengetahuan sains, mengidentifikasi pertanyaan, dan menarik kesimpulan berdasarkan bukti-bukti, dalam rangka memahami serta membuat keputusan berkenaan dengan alam dan perubahan yang dilakukan terhadap alam melalui aktivitas manusia (OECD, 2009). Definisi literasi sains ini memandangliterasi sains bersifat multidimensional. PISA juga mengungkapkan tiga dimensi besarliterasi sains, yaitu proses sains, konten sains, dan konteksaplikasi sains (Ovita dkk. 2014). Selain itu, pada hakikatnya IPA terbentuk atas kemampuan proses, produk dan sikap ilmiah (Lissa, 2018). Hal ini berkaitan dengan literasi sains.

Literasi sains merupakan kemampuan untuk mengaplikasikan pengetahuan ilmiah, mengidentifikasi pertanyaan-pertanyaan untuk memperoleh pengetahuan baru, dan menjelaskan suatu peristiwa secara ilmiah, dan mendapatkan kesimpulan berdasarkan fakta ilmiah (Sumini dan Ratnasari, 2019). Literasi sains yaitu kemampuan menerapkan proses ilmiah dan sikap ilmiah dalam situasi nyata, baik untuk diri sendiri maupun untuk masyarakat secara luas (Ratnasari, 2019). Literasi sains dianggap penting karena memahamai sains merupakan hal mendasar bagi kesiapan seseorang untuk hidup dalam masyarakat modern (Nuraini dkk. 2018). Pentingnya literasi sains karena permasalahan berkaitan dengan pengetahun dan teknologi. penguasaan literasi sains menurut Sholiha (2017) diharapkan dapat mempermudah siswa untuk beradaptasi dengan kemajuan ilmu pengetahuan dan teknologi dimasa mendatang. Rendahnya pencapaian literasi sains siswa di Indonesia dikarenakan kurangnya pembelajaran yang melibatkan proses sains seperti, memformulasikan pertanyaan ilmiah dalam penyelidikan, menggunakan pengetahuan yang dimiliki untuk menjelaskan fenomena alam serta menarik kesimpulan fakta yang diperoleh melalui penyelidikan (Rohayati, 2013). Selain itu, Penggunaan sumber belajar oleh guru biologi sering kali diabaikan bagaimana fungsi dari sumber belajar tersebut (Hamidah, 2017).

Mengingat pentingnya literasi sains, dan seringnya buku teks digunakan sebagai sumber ajar maka sebaiknya buku ajar yang digunakan dalam pembelajaran sains memenuhi muatan literasi sains, sehingga diharapkan literasi sains peserta didik akan meningkat. Selain itu, Analisis buku ajar IPA perlu dilakukan dengan tujuan untuk memperoleh informasi mengenai muatan literasi sains yang terdapat pada buku ajar yang digunakan oleh guru. Buku ajar yang berkualitas akan mempengaruhi keberhasilan pembelajaran. Nuraini dkk. (2017) memaparkan bahwa buku ajar yang banyak digunakan sebagai sumber belajar lebih banyak menekankan pada konten dan kurang menekankan pada pembelajaran. Dengan demikian buku ajar tersebut berpengaruh terhadap kemampuan literasi sains siswa.

Fakta ini menunjukan bahwa pembelajaran di Indonesia belum memberikan bekal kepada peserta didik untuk menggunakan konsepkonsep yang dipelajarinya dan belum menggunakan logika berpikir (menalar) dalam menyelesaikan soal (Yoga, 2015). Oleh sebab itu, perlu diadaknnya analisis literasi sains pada buku teks IPA SMP Kelas VII Kurikulum 2013. 


\section{Metode}

Jenis penelitian yang digunakan pada penelitian ini adalah metode penelitian kualitatif untuk memahami literasi sains dengan metode analisisisi, atau dokumen. Buku teks yang dianalisis adalah buku siswa SMP/MTs kelas VIII kurikulum 2013. Materi yang dipilih adalah materi sistem pencernaan pada manusia dan materi zat aditif dan zat adiktif.

Instrument yang digunakan sebagai alat untuk membantu menjaring data yang diperlukan yaitu lembar observasi yang berisi indikator literasi sains yang diadopsi dari Chiappetta \& Koballa (2010) dengan empat kategori berupa, sains sebagai batang tubuh pengetahuan, sains sebagai cara berfikir, sains sebagai cara menyelidiki, dan interaksi sains, teknologi, dan masyarakat.

Teknik observasi dalam penelitian ini adalah observasi analisis dokumen. Analisis dilakukan dengan membaca dan memahami unsur teks pada setiap halaman, bab, buku yang dianalisis dan mencocokan dengan

\section{Hasil dan Pembahasan}

Analisis literasi sains pada buku siswa mata IPA SMP/MTs berupa presentase tiap indikator literasi sains terdapat pada Gambar 1. Berdasarkan penelitian didapatkan rata-rata presentase keempat inikator literasi sains pada kedua bab yang dianalisis adalah sebagai berikut : sains sebagai batang tubuh $80 \%$, sains sebagai cara berfikir $75 \%$, sains sebagai cara menyelidiki $75,5 \%$, dan interaksi sains, teknologi dan masyarakat $72,5 \%$.

Hasil analisis dari kedua bab pada buku siswa SMP/MTs kelas delapan kurikulum 2013, menunjukan bahwa indikator sains sebagai batang tubuh pada kategori literasi sains lebih pernyataan indikator literasi sains sesuai lembar penilaian literasi sains.

Teknik pengelolaan data yang dilakukan pada penelitian ini adalah :

a. Menjumlahkan indikator literasi sains untuk setiap katagori pada buku siswa mata pelajaran IPA kelas VIII SMP/MTs yang dianalisis

b. Menghitung presentasi indikator kategori literasi sains pada setiap bab pada buku siswa kelas VIII SMP/MTs yang dianalisis dengan rumus : Presentase kategori literasi sains

$=$ Jumlah indikator per kategori $\times 100 \%$

Jumlah indikator total kategori

c. Menentukan rata-rata presentase literasi sains dari buku siswa yang dianalisis deengan rumus sebagai berikut

Total skor $(\mathrm{X})=\frac{\text { Epresentase } \text { skor literasi sains }}{4}$

d. Mendeskripsikan hasil analisis literasi sains pada buku siswa mata pelajaran IPA kelas VIII SMP/MTs.

e. Pembahasan

f. Menarik kesimpulan

dominan dari ketiga indikator lainnya. Secara umum buku yang dianalisis banyak menyajikan pengetahuan sains, yakni menyajikan fakta-fakta, kosep, prinsip, hukum dan hipotesis. Hal ini didukung oleh Abdulkarim (2017) yang menyatakan bahwa besarnya persentase penemuan kategori sains sebagai batang tubuh dibandingkan tiga kategori lainnya. Hal ini juga sejalan dengan Chiappetta \& Fillman (2007) dan Ramnarain \& Padayachee (2015).

Indikator kedua yang lebih dominan muncul adalah indikator sains sebagai cara menyelidiki sebesar 75,5\%. Pengaruh banyaknya kemunculan pada kedua bab adalah 
untuk mendorong siswa dalam mempelajari sains. Penelitian ini sejalan dengan Chiepetta \& Filman (2017) bahwa dalam penelitian ini yang termasuk dalam kategori ini adalah adanya eksperimen dan kegiatan langsung yang dapat dilakukan siswa untuk mendukung pemahaman konsep. Chiappetta (1991) menyatakan kategori sains sebagai cara menyelidiki ini digunakan untuk memanfaatkan beberapa pendekatan untuk mengkonstruksi pengetahuan.

Selanjutnya, ada indikator sains sebagai cara berfikir. Dari hasil analisis indikator ini memiliki presentase sebesar $75 \%$. Hal ini sesuai dengan penelitian dari buku teks yang dianalisis menunjukkan pendekatan yang dilakukan masih berupa hafalan. Pengaruh dari kategori sains sebagai cara berfikir yang dominan muncul adalah siswa kurang aktif dalam proses pembelajaran. Sejalan dengan Cobanoglu \& Sahin (2009) yang menunjukkan sedikit sekali situasi yang mengajak siswa untuk berpikir lebih tinggi pada isi materi.

Terakhir adalah interaksi sains, teknologi dan masyarakat. Pada kategori ini merupakan kategori yang memiliki proporsi paling sedikit dibandingkan kategori lainnya. Indikator yang menjelaskan manfaat sains dan teknologi bagi masyarakat memiliki proporsi paling banyak sedangkan menjelaskan pengaruh negatif sains dan teknologi bagi masyarakat masih sangat sedikit. Hasil analisis indikator interaksi sains, tekonolgi dan masyarakat memiliki presentasi $72,5 \%$. Hasil ini sejalan dengan penelitian Wahyu dkk (2014) yang menganalisis buku siswa mata pelajaran IPA Kelas VIII berdasarkan literasi sains dimana hasil penelitian yang didapat sebesar $4 \%$ untuk dimensi sains sebagai hubungan teknologi dan masyarakat.

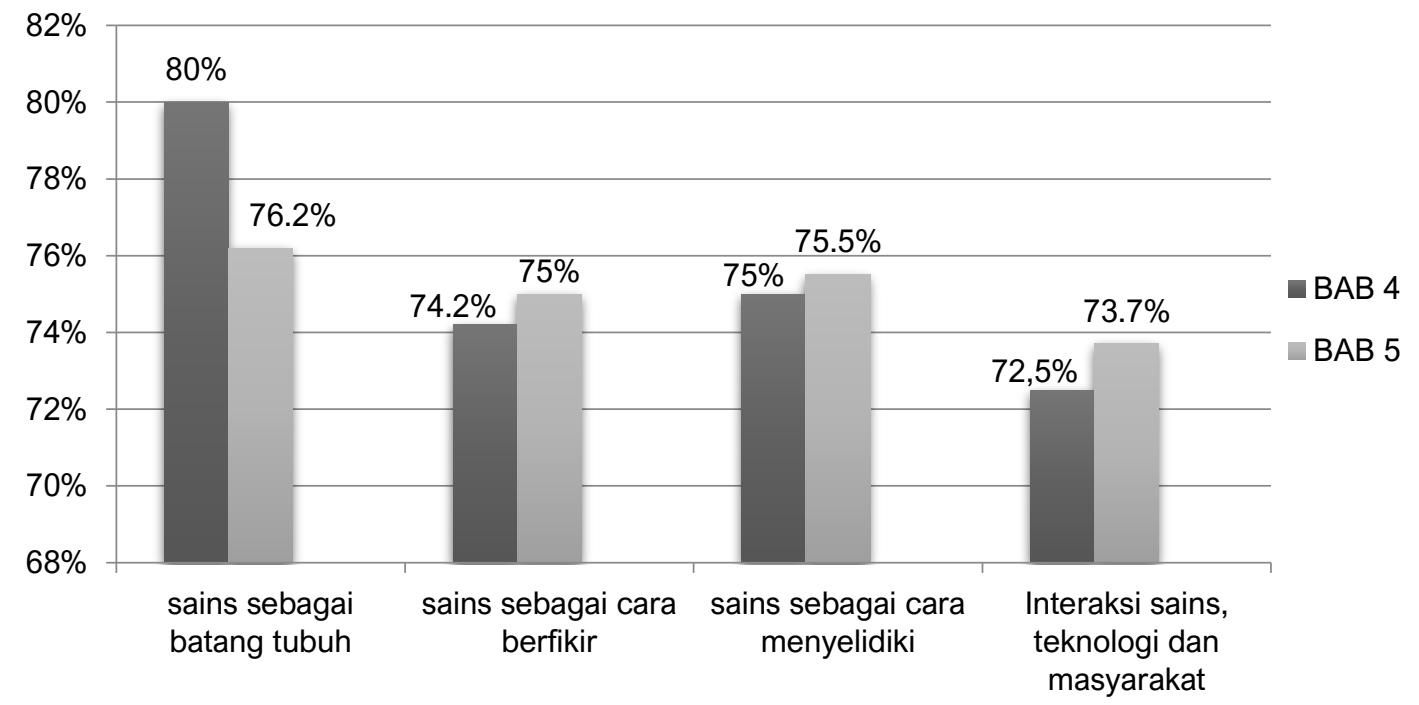

Gambar 1. Gambar Grafik Kategori Literasi Sains Pada Bab 4 dan Bab 5 


\section{Kesimpulan}

Berdasarkan hasil penelitian diperoleh simpulan bahwa tingkat literasi ilmiah buku siswa IPA SMP/MTs kelas VIII yang digunakan di Kabupaten Indramayu cukup baik sesuai dengan kriteria penilaian. Dimensi literasi sains yang banyak muncul pada buku teks

pelajaran IPA yang dianalisis adalah sains sebagai batang tubuh pengetahuan, diikuti sains sebagai jalan investigasi, sains sebagai jalan berpikir dan sains dan interaksinya dengan teknologi dan masyarakat.

\section{Daftar Pustaka}

1. Abdulkarim, A. "Analisis Isi Buku Teks Dan Implikasinya Dalam Membedakan Keterampilan Berfikir Siswa". Jurnal Forum Pendidikan. Vol 23, No 2, pp. 118132. 2007

2. Adisendjaja, Y. H. "Analisis Buku Biologi SMA kelas X di Kota Bandung Berdasarkan Literasi Sains". Jurusan Pendidikan Biologi FMIPA UPI. Bandung. Tidak diterbitkan. 2019

3. Chiapetta, Eugene. L. "A Method to Quantify Major Themes Of Scientific Literacy in Science Textbooks". Journal Of Research In Science Teaching.Vol. 28, No 8, p713-25, 1991

4. Chiappetta EL \& DA Filman. "Analysis of five high school biology textbooks used in the united states for inclusion of the nature of science". International Journal of Science Education.Vol. 29,No. 15, p1847-1848, 2014

5. Chiapetta EL \& TR Koballa. "Science Instruction In the middle And Secondary School : Developing Fundamental Knowlage And Skill". United State Of America : Pearson Education Inc. 2010

6. Hamidah,I. "Pengembangan Bahan Ajar Sub Bab Antioksidan Berbasis Kajian Pola Konsumsi Masyarakat Pesisir Indramayu". Journal of Innovative Science Education, vol. 6. No. 1,p59-65, 2017

7. Hamidah, I. "Lingkungan Sebagai Sumber Belajar Untuk Mengukur Pemahaman Konsep Siswa". Wacana Didaktika, vol. 3, No. 3, p35-42, 2017

8. Lissa. "Penggunaan Media Kunci Determinasi Terhadap Keterampilan Proses Sains Siswa Pada Materi Hewan Di SMA Negeri 1 Sindang". Jurnal Mangifera Edu, Vol. 2, No. 2, p71-78, 2018

9. Luzyawati, L., dan Hidayah, H. "Profil Miskonsepsi Siswa Dalam Materi Sistem Ekskresi Melalui Penugasan Peta Konsep”. Jurnal Mangifera Edu, Vol. 3, No. 2,p72-87, 2019 
10. Nur'aini, D. Rahardjo, S.B. \& Susanti, V. H. E. "Student' s profile about science literacy in Surakarta". Journal of Physics: Conf. Series 1022 01206, 1-6. 2018

11. Ovita, T. dkk. Skripsi. Pengembangan Media Pembelajaran Blog Berorientasi Literasi Sains Pada Sub Materil Perpindahan Kalor. FMIPA Universitas Negeri Surabaya. 2014

12. Ratnasari, A. Profil Kemampuan Literasi Sains Siswa Pada Pembelajaran Sistem Ekskresi. Prosiding Seminar Nasional Pendidikan, FKIP UNMA, 1-11, 2019

13. Rohayati, Tika. Skripsi. Pengaruh Pembelajaran Interaktif Demonstrasi Terhadap Peningkatan Literasi Sains Dan Sikap Ilmiah Siswa SMP Pada Materi Transfortasi Padaa Tumbuhan. Universitas Pendidikan Indonesia. 2013

14. Sholiha, S. Skripsi. Analis Aspek Literasi Sains Pada Buku Teks Pelajaran IPA Kelas V SD. PGSD Universitas Pasundan. 2017

15. Sumini dan Ratnasri, A. (2019). Analisis Perangkat Pembelajaran Materi Sistem Ekskresi Berdasarkan Literasi Sains. Prosiding Seminar Nasional Matematika dan Sains Departemen Pendidikan Matematika dan Pendidikan Biologi FKIP Universitas Wiralodra, 137-144, 2019 